\title{
Some Aspects of Capability-based Planning in the Field of National Security
}

Artem Bratko Ph. D. in Military Sciences, Associate Professor of the General Military Disciplines Department, Bohdan Khmelnytskyi National Academy of the State Border Guard Service of Ukraine, Khmelnytskyi, Ukraine. E-mail: bratkoav84@gmail.com

ORCID: https://orcid.org/0000-0001-5503-3318

Anton Datskov Ph. D. in Psychology, Professor of the Department of Military Arts, Bohdan Khmelnytskyi National Academy of the State Border Guard Service of Ukraine, Khmelnytskyi, Ukraine. E-mail: datskovanton@gmail.com

ORCID: https://orcid.org/0000-0001-7110-8666

Dmytro Oleshko Ph. D. in Psychology, Lecturer of the of the Border Guard Service Department, Bohdan Khmelnytskyi National Academy of the State Border Guard Service of Ukraine, Khmelnytskyi, Ukraine. Email: oleshko104@ukr.net

ORCID: https://orcid.org/0000-0001-7515-1629

Valerii Vychavka Lecturer of the Legal Department, Bohdan Khmelnytskyi National Academy of the State Border Guard Service of Ukraine, Khmelnytskyi, Ukraine. E-mail: v251287@gmail.com ORCID: http://orcid.org/0000-0003-0052-8246

Oleksandr Olytskyi Post Graduate Student, Bohdan Khmelnytskyi National Academy of the State Border Guard Service of Ukraine, Khmelnytskyi, Ukraine. E-mail: olytskiyo@ukr.net

ORCID: http://orcid.org/0000-0003-3502-1234

Article History: Received: 10 November 2020; Revised 12 January 2021 Accepted: 27 January 2021; Published online: 5 April 2021

\begin{abstract}
The State Border Guard Service of Ukraine is a component of the security and defense sector and the new conditions the border agency operates in arise the issue on improving the methodology of planning its operational and service activities. The authors propose to improve the methodology of operational and service activities planning based on the methodology of defense planning within the national security system on the basis of opportunities. The capability-based planning will allow for better planning of operational and service activities of the border agency and will ensure active cooperation between Ukraine and NATO in order to achieve the criteria necessary for full membership in the Alliance. A defense survey is conducted to assess the state and readiness of the defense forces to perform tasks related to the defense of Ukraine, the state of their personnel, financial, logistical and other types of support in the current and projected conditions of the security environment. The survey of the state of the State Border Guard Service of Ukraine was conducted using an analytical method, namely the analysis of strengths and weaknesses, opportunities and threats (SWOT-analysis), which allows substantiating the main directions of the Development Strategy of the State Border Guard Service of Ukraine and increasing the level of operational and service activities planning within the system of national security.
\end{abstract}

Keywords: decision analysis, methodology, planning, operational and service activities, national security

\section{Introduction}

First Paragraph: use this for the first paragraph in a section. Ensuring national security is certainly important in the context of the overall development of any state and the realization of its national interests.

The State Border Guard Service of Ukraine (hereinafter referred to as - the SBGSU) carries out its development within the framework of the general reform of the security and defense sector of Ukraine and provides not only surveillance but also protection of the state border.

The analysis of the events of recent years has changed the conditions of the SBGSU operation, which has led to the improvement of the existing methods and approaches to the planning of operational and service activities and further development (reform) of the agency. 
Capability-based planning in the SBGSU is one of the promising methods of planning in the field of state border security, the peculiarity of which is the elaboration of forces opportunities to effectively counter threats and risks of both military and non-military nature, taking into account probable scenarios of conflict (crisis) situations development on a long-term horizon. This method of planning is the main one in NATO member countries.

\section{Literature review}

The scientific works (Rusnak, 2017; Horbulin, 2017) revealed the research on the activities of organization and planning of the Armed Forces of Ukraine (hereinafter referred to as - the Armed Forces) and other components of the security and defense sector concerning the development of security and defense forces opportunities. The authors (Kosevtsov, 2020; Bondarenko, 2021) investigated capability-based strategic planning in terms of results-oriented management approaches. The current state and further development of the defense planning system in the Armed Forces of Ukraine is described by the authors (Romanchenko at all, 2017).

The monograph (Pavlikovskyi at all, 2020), devoted to defense management, outlines the latest approaches to the implementation of a systematic approach to defense management in the Ministry of Defense, the Armed Forces of Ukraine and other defense forces with the aim to improve defense reform and approximate NATO standards. Accordingly, the topical issue of implementing the capability-based planning process in the SBGSU is left in abeyance.

\section{Materials and Methods}

Planning is the main function of management, which combines all managerial functions. An organization cannot clearly define its goals and activities without planning. This type of management environment determines the prospects and future state of the organization, ways and means to achieve them.

The planning process helps to make informed management decisions. Its purpose is to determine the required amount of resources, implement innovations to adequately respond to change, and so on.

Defense planning is an integral part of the system of state strategic planning, carried out to ensure the defense opportunities of the state by determining the priorities and directions of defense forces development, their opportunities, armaments and military equipment, infrastructure, training of troops (forces), and the formulation of relevant concepts, programs and plans taking into account the real potential threats in the military sphere as well as the financial and economic opportunities of the state.

The initial stage of planning the operational and service activities of the SBGSU is a survey of its opportunities (survey of its state). The objective of the SBGSU opportunities survey is to determine (specify) the lists of available and required opportunities, to form a list of critical opportunities for further development (specification, amendments to) the Unified List (Catalogue) of the Defense Forces opportunities (hereinafter referred to as - the Defense Forces Opportunities Catalogue) and Functional Opportunities Groups determining the division of responsibilities for their maintenance and development planning.

The following methods and tools of strategic analysis are used in order to support the process of forming proposals for management decisions making:

Delphi expert assessment method (Delphi Technique);

methods of complex analysis (PEST analysis, political, economic, socio-cultural and technological);

methods of analysing strengths and weaknesses, opportunities and threats (SWOT; strengths, weaknesses, opportunities and threats analysis);

gap analysis technique (Gap Analysis);

risk profiling technique (Risk Profiling).

The result of the opportunities survey is the development of the Defense Forces Opportunities Catalogue and Functional Opportunities Groups determining the division of responsibilities for their maintenance and development planning.

The results of the opportunities survey are further used during the defense survey, as well as for the development of draft strategies, concepts, government programs and other strategic documents that define the main directions and objectives of the state defense policy (Saganiuk at all, 2019).

\section{Results of Research}

The SBGSU is a component of the security and defense sector and a demand was created to conduct a survey of the situation based on the methodology of analysis of strengths and weaknesses, opportunities and threats (SWOT-analysis) with the change of conditions and further development.

The procedure in SWOT is to segregate the available information about the case into four groups (categories of strategic factors):

S stands for strengths: everything that is the advantages, positive characteristics of the analysed object; 
W stands for weaknesses: everything that is characterised by fragility, obstacles, defects of the analysed object;

O stands for opportunities: everything that creates the chance for useful changes in terms of the analysed object;

$\mathrm{T}$ stands for threats: everything that creates the danger of useless changes in regard to the analysed object.

The strengths and weaknesses of the SBGSU in the conditions of daily activities, in the conditions of complicating the situation and in war-time conditions, as well as opportunities and threats in certain conditions are analysed.

The initial data are the existing legal framework, scenarios and situations of development of the militarypolitical situation, functions and responsibilities. The purpose of the assessment is to determine the directions of further development of the SBGSU.

The importance of strengths (Table 1) and weaknesses, as well as opportunities (Table 2) and threats (Table 3 ) was determined by expert assessment method. The importance is defined from 1 to 10 , where 1 is the least important, 10 is the most important value.

Table 1. Assessment of the strengths significance in a complicated situation

\begin{tabular}{|c|c|c|c|c|c|c|c|c|c|c|c|c|}
\hline \multirow{2}{*}{$\begin{array}{c}\text { Strengths in a } \\
\text { complicated } \\
\text { situation }\end{array}$} & 1 & 2 & 3 & 4 & 5 & 6 & 7 & 8 & 9 & 10 & $\sum$ & $\begin{array}{c}\text { Significance } \\
\text { of strengths }\end{array}$ \\
\hline & 7 & 7 & 6 & 8 & 4 & 5 & 4 & 5 & 4 & 6 & 56 & 0.101 \\
\hline 2 & 3 & 2 & 2 & 1 & 1 & 3 & 2 & 2 & 1 & 3 & 20 & 0.036 \\
\hline 3 & 9 & 10 & 7 & 7 & 6 & 10 & 8 & 8 & 9 & 10 & 84 & 0.152 \\
\hline 4 & 8 & 9 & 10 & 10 & 7 & 9 & 7 & 9 & 8 & 7 & 84 & 0.152 \\
\hline 5 & 6 & 7 & 8 & 6 & 10 & 7 & 10 & 7 & 7 & 8 & 76 & 0.138 \\
\hline 6 & 4 & 6 & 5 & 4 & 5 & 6 & 5 & 4 & 5 & 4 & 48 & 0.087 \\
\hline 7 & 10 & 8 & 9 & 9 & 8 & 8 & 9 & 10 & 10 & 9 & 90 & 0.163 \\
\hline 8 & 2 & 3 & 1 & 3 & 3 & 2 & 1 & 1 & 2 & 1 & 19 & 0.034 \\
\hline 9 & 1 & 1 & 3 & 2 & 2 & 1 & 3 & 3 & 3 & 2 & 21 & 0.038 \\
\hline 10 & 5 & 2 & 4 & 5 & 9 & 4 & 6 & 6 & 6 & 5 & 52 & 0.094 \\
\hline$\sum$ & 55 & 55 & 55 & 55 & 55 & 55 & 55 & 55 & 55 & 55 & 550 & 1 \\
\hline
\end{tabular}

Strengths in a complicated situation:

1. ensuring the rhythmic functioning of the entry-exit check points and passing persons and transport across the administrative border;

2. monitoring the surface situation, especially in the vicinity of the Kerch Strait, and the situation around the arrival of foreign vessels into the closed ports of Ukraine on the temporary occupied territory of the ARC, covering road steads of the Ukrainian ports and the sea coast from possible landing of enemy sabotage groups;

3. reorganization of combat reserve units (rapid response border commands, mobile border outposts) and bringing their structure to a single model, the use of the SBGSU special action personnel to strengthen the protection of the state border in the active directions of illegal activities;

4. improving the system of detecting terrorist threats to national security on the state border of Ukraine by obtaining advance information on separate individuals, groups and organizations whose actions are aimed at preparing and committing terrorist acts, as well as attempts to use illegal migration channels by international terrorist organizations;

5. carrying out a set of measures to prevent interference of neighbouring countries into the domestic political process in the border regions;

6. effective involvement of additional forces (reserves) with the use of modern technical means of surveillance (UAVs, drones) during the complication of the situation on the state border;

7. preparedness of the personnel for sudden actions in case of complication of the situation and clear interaction of all components of the operation;

8. involvement of border aircraft fleet in measures to search for and identify violators of legislation on border issues;

9. involvement of dog handlers with service dogs in the search, pursuit and detention of offenders on the green border, as well as the use of service dogs at all types of border crossing points;

10. participation in measures aimed at combating terrorism, as well as the cessation of activities of illegal paramilitary or armed formations (groups), organized groups and criminal organizations that have violated the procedure for crossing the state border of Ukraine. 
Table 2. Assessment of opportunities

\begin{tabular}{|c|c|c|c|c|c|c|c|c|c|c|c|c|}
\hline \multirow{2}{*}{ Opportunities } & \multicolumn{10}{|c|}{ Experts } & \multirow{2}{*}{$\begin{array}{c}\text { Significance } \\
\text { of } \\
\text { of } \\
\text { opportunities }\end{array}$} \\
\hline 1 & 1 & 2 & 3 & 4 & 5 & 6 & 7 & 8 & 9 & 10 & 2 & 0.152 \\
\hline 2 & 8 & 7 & 10 & 10 & 7 & 7 & 8 & 10 & 9 & 8 & 84 & 0.138 \\
\hline 3 & 7 & 10 & 7 & 7 & 9 & 8 & 7 & 7 & 7 & 7 & 76 & 0.058 \\
\hline 4 & 5 & 1 & 4 & 2 & 4 & 5 & 1 & 5 & 3 & 2 & 32 & 0.061 \\
\hline 5 & 4 & 4 & 2 & 3 & 5 & 6 & 3 & 2 & 1 & 3 & 34 & 0.076 \\
\hline 6 & 3 & 2 & 1 & 4 & 6 & 4 & 6 & 3 & 4 & 4 & 42 & 0.032 \\
\hline 7 & 9 & 8 & 8 & 9 & 10 & 9 & 9 & 8 & 10 & 9 & 89 & 0.161 \\
\hline 8 & 10 & 9 & 9 & 8 & 8 & 10 & 10 & 9 & 8 & 10 & 91 & 0.165 \\
\hline 9 & 2 & 5 & 6 & 5 & 1 & 2 & 5 & 4 & 5 & 6 & 41 & 0.074 \\
\hline 10 & 1 & 6 & 5 & 6 & 3 & 1 & 4 & 6 & 6 & 5 & 43 & 0.078 \\
\hline$\sum$ & 55 & 55 & 55 & 55 & 55 & 55 & 55 & 55 & 55 & 55 & 550 & 1 \\
\hline
\end{tabular}

Opportunities:

1. to take measures to end armed conflicts and provocations on the state border of Ukraine in cooperation with representatives of the National Guard;

2. to take measures to prevent the mass crossing of the state border of Ukraine from the territory of neighbouring states together with other law enforcement agencies;

3. to carry out operational measures to identify and eliminate channels of illegal migration in cooperation with representatives of law enforcement agencies of other countries;

4. to create an integrated system of surveillance throughout the state border of Ukraine on the basis of innovative engineering solutions in order to ensure adequate response to existing and potential threats to national security in accordance with the standards of the European Union and NATO;

5. to take measures to identify and detain persons involved in illegal activities within the competence of the SBGSU in cooperation with representatives of law enforcement agencies of other states;

6. to continue intensification of international cooperation with law enforcement agencies and organizations such as Interpol, Europol, Eurojust;

7. to carry out joint preventive measures and special border operations on the state border of Ukraine;

8. to repel an invasion or attack on the territory of Ukraine by the armed forces of other states or groups of states together with cooperating bodies;

9. to provide the ability for coordinated activities of military formations and relevant law enforcement agencies related to surveillance of the state border of Ukraine and access to and from the temporarily occupied territory, as well as the activities of state bodies exercising various types of control when crossing the state border of Ukraine and access to and from the temporarily occupied territory or participate in ensuring the regime of the state border, border regime and regime at the border crossing points across the state border of Ukraine and at the entry-exit checkpoints;

10. to strengthen the coordination activities of the SBGSU within the system of integrated border management.

Table 3. Assessment of threats

\begin{tabular}{|c|c|c|c|c|c|c|c|c|c|c|c|c|}
\hline \multirow{2}{*}{ Threats } & \multicolumn{10}{|c|}{ Experts } & \multirow{2}{*}{$\sum$} & $\begin{array}{c}\text { Significance } \\
\text { of threats }\end{array}$ \\
\cline { 2 - 14 } & 1 & 2 & 3 & 4 & 5 & 6 & 7 & 8 & 9 & 10 & & 0.141 \\
\hline 1 & 7 & 8 & 10 & 6 & 7 & 8 & 5 & 9 & 9 & 9 & 78 & 0.132 \\
\hline 2 & 8 & 7 & 9 & 5 & 8 & 7 & 7 & 7 & 7 & 8 & 73 & 0.138 \\
\hline 3 & 9 & 9 & 7 & 9 & 6 & 9 & 6 & 5 & 6 & 10 & 76 & 0.034 \\
\hline 4 & 1 & 1 & 3 & 1 & 3 & 3 & 1 & 2 & 1 & 3 & 19 & 0.147 \\
\hline 5 & 10 & 10 & 8 & 8 & 5 & 6 & 10 & 8 & 10 & 9 & 81 & 0.038 \\
\hline 6 & 3 & 2 & 1 & 3 & 2 & 1 & 3 & 3 & 2 & 1 & 21 & 0.065 \\
\hline 7 & 2 & 4 & 4 & 4 & 4 & 4 & 2 & 4 & 4 & 4 & 36 & 0.043 \\
\hline 8 & 4 & 3 & 2 & 2 & 1 & 2 & 4 & 1 & 3 & 2 & 24 & 0.112 \\
\hline 9 & 6 & 5 & 6 & 7 & 9 & 5 & 8 & 6 & 5 & 4 & 62 & 0.145 \\
\hline 10 & 5 & 6 & 5 & 10 & 10 & 10 & 9 & 10 & 8 & 7 & 80 & 1 \\
\hline$\Sigma$ & 55 & 55 & 55 & 55 & 55 & 55 & 55 & 55 & 55 & 55 & 550 & 1 \\
\hline
\end{tabular}

Threats: 
1. incomplete process of demarcation of the Ukrainian-Moldovan, Ukrainian-Belarusian and UkrainianRussian sectors of the state border;

2. low level of well-being of the population of inhabitants of frontier areas of Ukraine provokes to implementation of illegal activities on the state border;

3. the spread of international crime, in particular in the sphere of drug trafficking, human trafficking, illegal migration, proliferation of weapons of mass destruction;

4. the current pace of rearmament to the latest (modernized) models does not meet the need to replace the main types of weapons and military equipment of Soviet production, which will soon run out of resources;

5. insufficient funding of the SBGSU and implementation of measures to develop the border agency;

6. periodic complications in the operation of existing border crossing points due to seasonal and other changes in cross-border traffic flows;

7. incomplete process of arrangement of the state border with the latest engineering and technical means;

8. obsolete fleet of aircraft and ship-cutter composition results in a decrease in their effective use for the state border surveillance;

9. insufficient interaction with law enforcement agencies within the system of integrated border management;

10. imperfection of the regulatory and legal framework in the field of border security.

The next step is to determine the importance of strengths and opportunities (Table 4), as well as strengths and threats (Table 5).

Table 4. Table determining the significance of strengths and opportunities

\begin{tabular}{|c|c|c|c|c|c|c|c|c|c|c|c|c|c|}
\hline \multirow[b]{2}{*}{$\begin{array}{l}\text { Opportuni } \\
\text { ties }\end{array}$} & \multicolumn{10}{|c|}{ Strengths in a complicated situation } & \multirow[b]{2}{*}{$\Sigma$} & \multirow{2}{*}{$\begin{array}{l}\text { Significa } \\
\text { nce of } \\
\text { opportuni } \\
\text { ties }\end{array}$} & \multirow[b]{2}{*}{$\begin{array}{c}\sum \mathrm{x} \\
\text { capabil } \\
\text { ity }\end{array}$} \\
\hline & 1 & 2 & 3 & 4 & 5 & 6 & 7 & 8 & 9 & 10 & & & \\
\hline 1 & 2 & 0 & 1 & 3 & 1 & 2 & 2 & 1 & 2 & 3 & 17 & 0.152 & 2.584 \\
\hline 2 & 3 & 0 & 1 & 2 & 1 & 2 & 3 & 1 & 1 & 3 & 17 & 0.138 & 2.346 \\
\hline 3 & 0 & 1 & 2 & 3 & 0 & 1 & 2 & 0 & 1 & 1 & 11 & 0.058 & 0.638 \\
\hline 4 & 1 & 1 & 1 & 2 & 0 & 3 & 2 & 1 & 1 & 1 & 13 & 0.061 & 0.793 \\
\hline 5 & 1 & 1 & 2 & 2 & 2 & 0 & 1 & 1 & 1 & 3 & 14 & 0.076 & 1.064 \\
\hline 6 & 2 & 0 & 1 & 3 & 0 & 1 & 1 & 1 & 1 & 3 & 13 & 0.032 & 0.416 \\
\hline 7 & 1 & 2 & 3 & 3 & 2 & 3 & 3 & 3 & 3 & 3 & 26 & 0.161 & 4.186 \\
\hline 8 & 1 & 3 & 3 & 3 & 1 & 3 & 3 & 3 & 3 & 3 & 26 & 0.165 & 4.29 \\
\hline 9 & 3 & 1 & 2 & 2 & 1 & 2 & 3 & 0 & 3 & 2 & 19 & 0.074 & 1.406 \\
\hline 10 & 2 & 2 & 2 & 2 & 1 & 2 & 3 & 1 & 1 & 2 & 18 & 0.078 & 1.404 \\
\hline$\sum$ & 16 & 11 & 18 & 25 & 9 & 19 & 23 & 12 & 17 & 24 & 348 & 1 & 19.127 \\
\hline $\begin{array}{l}\text { Significan } \\
\text { ce of } \\
\text { strengths }\end{array}$ & $\begin{array}{r}0.10 \\
1\end{array}$ & $\begin{array}{r}0.03 \\
6\end{array}$ & $\begin{array}{r}0.15 \\
2\end{array}$ & $\begin{array}{r}0.15 \\
2\end{array}$ & $\begin{array}{r}0.13 \\
8\end{array}$ & $\begin{array}{r}0.08 \\
7\end{array}$ & $\begin{array}{r}0.16 \\
3\end{array}$ & $\begin{array}{r}0.03 \\
4\end{array}$ & $\begin{array}{r}0.03 \\
8\end{array}$ & $\begin{array}{r}0.09 \\
4\end{array}$ & 1 & & \\
\hline $\begin{array}{c}\sum \mathrm{x} \\
\text { significan } \\
\text { ce of } \\
\text { strengths }\end{array}$ & $\begin{array}{c}1.61 \\
6\end{array}$ & $\begin{array}{c}0.39 \\
6\end{array}$ & $\begin{array}{c}2.73 \\
6\end{array}$ & 3.8 & $\begin{array}{c}1.24 \\
2\end{array}$ & $\begin{array}{c}1.65 \\
3\end{array}$ & $\begin{array}{c}3.74 \\
9\end{array}$ & $\begin{array}{c}0.40 \\
8\end{array}$ & $\begin{array}{c}0.64 \\
6\end{array}$ & $\begin{array}{c}2.25 \\
6\end{array}$ & $\begin{array}{c}18.5 \\
02\end{array}$ & & 37.629 \\
\hline
\end{tabular}

Table 5. Table determining the significance of strengths and threats

\begin{tabular}{|c|c|c|c|c|c|c|c|c|c|c|c|c|c|}
\hline \multirow[b]{2}{*}{ Threats } & \multicolumn{10}{|c|}{ Strengths in a complicated situation } & \multirow[b]{2}{*}{$\Sigma$} & \multirow{2}{*}{$\begin{array}{c}\text { Significa } \\
\text { nce of } \\
\text { threats }\end{array}$} & \multirow{2}{*}{$\begin{array}{c}\sum_{\text {threa }} \mathrm{x} \\
\text { ts } \\
\end{array}$} \\
\hline & 1 & 2 & 3 & 4 & 5 & 6 & 7 & 8 & 9 & 10 & & & \\
\hline 1 & 1 & 0 & 1 & 3 & 3 & 1 & 2 & 2 & 2 & 2 & 17 & 0.141 & 2.397 \\
\hline 2 & 1 & 0 & 1 & 2 & 2 & 1 & 1 & 2 & 2 & 2 & 14 & 0.132 & 1.848 \\
\hline 3 & 2 & 0 & 2 & 3 & 2 & 2 & 1 & 1 & 1 & 3 & 17 & 0.138 & 2.346 \\
\hline 4 & 1 & 2 & 3 & 1 & 0 & 3 & 1 & 1 & 1 & 1 & 14 & 0.034 & 0.476 \\
\hline 5 & 3 & 3 & 3 & 1 & 1 & 1 & 1 & 3 & 1 & 1 & 18 & 0.147 & 2.646 \\
\hline 6 & 3 & 0 & 0 & 0 & 1 & 1 & 2 & 1 & 1 & 2 & 11 & 0.038 & 0.418 \\
\hline 7 & 3 & 0 & 2 & 2 & 0 & 3 & 0 & 1 & 1 & 1 & 13 & 0.065 & 0.845 \\
\hline 8 & 0 & 3 & 1 & 1 & 1 & 0 & 0 & 3 & 0 & 1 & 10 & 0.043 & 0.43 \\
\hline 9 & 1 & 1 & 1 & 3 & 3 & 1 & 3 & 0 & 0 & 3 & 16 & 0.112 & 1.792 \\
\hline 10 & 1 & 1 & 1 & 3 & 1 & 0 & 0 & 0 & 0 & 3 & 10 & 0.145 & 1.45 \\
\hline
\end{tabular}




\begin{tabular}{|c|c|c|c|c|c|c|c|c|c|c|c|c|c|}
\hline$\sum$ & 16 & 10 & 15 & 19 & 14 & 13 & 11 & 14 & 9 & 19 & 280 & 1 & $\begin{array}{c}14.64 \\
8\end{array}$ \\
\hline $\begin{array}{c}\text { Significa } \\
\text { nce of } \\
\text { strengths }\end{array}$ & $\begin{array}{c}0.10 \\
1\end{array}$ & $\begin{array}{c}0.03 \\
6\end{array}$ & $\begin{array}{c}0.15 \\
2\end{array}$ & $\begin{array}{c}0.15 \\
2\end{array}$ & $\begin{array}{c}0.13 \\
8\end{array}$ & $\begin{array}{c}0.08 \\
7\end{array}$ & $\begin{array}{c}0.16 \\
3\end{array}$ & $\begin{array}{c}0.03 \\
4\end{array}$ & $\begin{array}{c}0.03 \\
8\end{array}$ & $\begin{array}{c}0.09 \\
4\end{array}$ & 1 & & \\
\hline $\begin{array}{c}\sum \mathrm{x} \\
\text { significan } \\
\text { ce of } \\
\text { strengths }\end{array}$ & $\begin{array}{c}1.61 \\
6\end{array}$ & 1.52 & 2.28 & $\begin{array}{c}2.88 \\
8\end{array}$ & $\begin{array}{c}1.93 \\
2\end{array}$ & $\begin{array}{c}1.13 \\
1\end{array}$ & $\begin{array}{c}1.79 \\
3\end{array}$ & $\begin{array}{c}0.47 \\
6\end{array}$ & $\begin{array}{c}0.34 \\
2\end{array}$ & $\begin{array}{c}1.78 \\
6\end{array}$ & $\begin{array}{c}15.76 \\
4\end{array}$ & & $\begin{array}{c}30.41 \\
2\end{array}$ \\
\hline
\end{tabular}

The generalized data of strengths and weaknesses of the SBGSU in the conditions of daily activities, in the conditions of complication of the situation and in war-time conditions, opportunities and threats are reflected in Table 6.

Table 6. Table of strengths and weaknesses, opportunities and threats

\begin{tabular}{|c|c|c|c|c|c|c|}
\hline \multirow{2}{*}{ Combination } & \multicolumn{2}{|c|}{ Conditions of daily activities } & \multicolumn{2}{c|}{$\begin{array}{c}\text { Conditions of complication of } \\
\text { the situation }\end{array}$} & \multicolumn{2}{c|}{ War-time conditions } \\
\cline { 2 - 7 } & $\begin{array}{c}\text { Sum of } \\
\text { relationships }\end{array}$ & $\begin{array}{c}\text { Sum of } \\
\text { productions }\end{array}$ & $\begin{array}{c}\text { Sum of } \\
\text { relationships }\end{array}$ & $\begin{array}{c}\text { Sum of } \\
\text { productions }\end{array}$ & $\begin{array}{c}\text { Sum of } \\
\text { relationships }\end{array}$ & $\begin{array}{c}\text { Sum of } \\
\text { productions }\end{array}$ \\
\hline $\begin{array}{c}\text { Strengths - } \\
\text { opportunities }\end{array}$ & 279 & 27.8 & 348 & 37.6 & 402 & 43.4 \\
\hline $\begin{array}{c}\text { Weaknesses - } \\
\text { opportunities }\end{array}$ & 398 & 39.9 & 420 & 42.5 & 452 & 47.3 \\
\hline $\begin{array}{c}\text { Strengths - } \\
\text { threats }\end{array}$ & 304 & 30.9 & 280 & 30.4 & 426 & 44.4 \\
\hline $\begin{array}{c}\text { Weaknesses - } \\
\text { threats }\end{array}$ & 362 & 36.8 & 366 & 38.3 & 412 & 41.7 \\
\hline
\end{tabular}

\section{Conclusions}

Thus, the analysis identifies the strengths and weaknesses of the border agency, opportunities and threats in the daily activities, in the conditions of the situation complication and in war-time conditions, which can further be used in the development of strategic documents, namely the Development Strategy of the State Border Guard Service of Ukraine. The existing legal framework, scenarios and situations of development of the militarypolitical situation, functions and responsibilities of the border agency make the output information. The importance of the main parameters was determined by the method of expert assessment and the directions of further development of the State Border Guard Service of Ukraine to ensure the effective use of the border agency in a fundamentally new environment in the conditions of daily activities, in the conditions of complication of the situation and in war-time conditions, opportunities and threats were substantiated with the help of SWOT analysis. The SWOT analysis is an adequate method for strategic analysis, which allows to determine the directions of development of units and subdivisions of the State Border Guard Service of Ukraine and substantiation of their tasks, and can be used to assess the state of similar structures and organizations during planning processes.

\section{References}

[1]. Bondarenko, S., Tkach, I., Drobotov, S., Mysyk, A., \& Plutytska, K. (2021). National Resilience as A Determinant of National Security of Ukraine. Journal of Optimization in Industrial Engineering, 14(1), 111-117.

[2]. Defense Reform: a Systematic Approach to Defense Management : Monograph / A. Pavlikovskyi, V. Frolov, F. Sahaniuk et al ; under the general editorship of Dr. of Mil. Sciences A. Syrotenko. Kyiv : the National Defense University of Ukraine, 2020. 274 p

[3]. Defense Review: Ukrainian Dimension 2014-2018: monograph / F. Sahaniuk, A. Pavlikovskyi, P. Shchypanskyi, V. Pavlenko et al; under the general editorship of Dr. of Mil. Sciences, Prof. I. Rusnak. Kyiv: the Ministry of Defense and General Staff of the Armed Forces of Ukraine, the National Defense University of Ukraine, 2019. 196 p.

[4]. Horbulin, V. P., \& Krykun, P. M. (2017). Development of Defense Planning as a Component of the National Planning System in the Field of Security and Defense in the Context of Approximation to NATO Procedures and Standards: an Analytical Note. Kyiv: NISS. 
[5]. Kosevtsov, V., Telelim, V., Lobanov, A., \& Punda, Y. (2020). Development and Implementation of the Target Function in the Decision-Making Process in the System of Providing the Military Security of the State. Eastern-European Journal of Enterprise Technologies, 5(3), 107.

[6]. Malyshev, O. V., Malysheva,N. R., Kalmykov,V. H., \& Levchuk, O. V. (2020). Capability-Based Defense Planning in Ukraine: Current State and Prospects. Collection of Scientific Works of the Centre for Military Strategic Studies of Ivan Cherniakhovskyi National Defense University of Ukraine, 54-61.

[7]. Mudrak, Yu. M. (2020). Approaches to the Implementation of NATO Standards in the Armed Forces of Ukraine. Collection of Scientific Works of the Centre for Military Strategic Studies of Ivan Cherniakhovskyi National Defense University of Ukraine, (2-69), 6-10.

[8]. Poliaiev, A. I. (2020). Some Aspects of Defense Management Implementation in the Defense Agencies of NATO Member States. Collection of Scientific Works of the Centre for Military Strategic Studies of Ivan Cherniakhovskyi National Defense University of Ukraine, 70-74.

[9]. Rusnak, I. S., \& Melikhov, O. A. (2018). Defense Reform in Ukraine: Achievements and Horizons. Science and defense, 2(1), 3-10.

[10]. Rusnak, I. S., Petrenko, A. H., Yakovenko, A. V., Romaniuk, I. M., \& Kokhno, V. D. (2017). Capability-Based Defense Planning: Peculiarities and Implementation Prospects. Science and Defense, (2), 3-10.

[11]. Trembovetskyi, O. H., Bratko, A. V., \& Hulevatyi, D. Yu. (2018). Recommendations on the Development of Forces and Means of the State Border Guard Service of Ukraine for Action in the Context of the Joint Forces Operation. Collection of Scientific Works of Kharkiv National University of the Air Force, (4), 15-22. 